\title{
Modulation of crystalline Proteus mirabilis biofilm development on urinary catheters
}

Correspondence

David J. Stickler

stickler@cardiff.ac.uk

Received 7 November 2005

Accepted 10 January 2006

\author{
David J. Stickler and Sheridan D. Morgan \\ Cardiff School of Biosciences, Cardiff University, Cardiff CF10 3TL, UK
}

\section{INTRODUCTION}

Infection by Proteus mirabilis can seriously complicate the care of patients undergoing long-term indwelling bladder catheterization (Stickler \& Zimakoff, 1994). These ureaseproducing bacteria colonize the catheter surfaces forming extensive biofilm communities. They are capable of generating ammonia from urea and elevating the $\mathrm{pH}$ of the urine and biofilm. Under these conditions, crystals of calcium and magnesium phosphate precipitate in the urine and in the developing biofilm. Aggregates of crystals and bacteria form in the urine and these also become incorporated into the developing crystalline biofilm (Morris et al., 1999). Under these circumstances, urine can leak around the outside of the catheter and patients become incontinent. Alternatively, urine is retained within the bladder, causing painful distension of the bladder. Reflux of infected urine to the kidneys can then precipitate serious symptomatic episodes such as pyelonephritis, septicaemia and endotoxic shock (Kunin, 1997). All available types of indwelling catheter are vulnerable to this problem (Morris et al., 1997) and currently there are no effective procedures available for its control (Kunin, 1997).

Urinary $\mathrm{pH}$ is an important factor in the process of catheter encrustation. Hedelin et al. (1991) found little encrustation on the catheters of patients whose mean urinary $\mathrm{pH}$ was below $6 \cdot 8$ and suggested that this was the critical urinary
$\mathrm{pH}$ above which crystal formation occurred. Choong et al. (2001) reported that, in patients whose catheters blocked, the mean $\mathrm{pH}$ at which crystals formed in their urine (the nucleation $\mathrm{pH}, \mathrm{pH}_{\mathrm{n}}$ ) was $7 \cdot 58$. The mean $\mathrm{pH}_{\mathrm{n}}$ of the urine from 'non-blockers' $(7 \cdot 66)$ was not significantly different from this value. The mean $\mathrm{pH}$ of the urine voided by the 'blockers' $\left(\mathrm{pH}_{\mathrm{v}}\right)$, however, was $7 \cdot 85$ compared with $6 \cdot 26$ in the case of the 'non-blockers'. The recent prospective study of Mathur et al. (2006) showed that the $\mathrm{pH}_{\mathrm{n}}$ of the urine of catheterized patients varied among individuals and varied from week to week in any one individual. This study also confirmed that catheter encrustation was most common and rapid in those patients where there was no safety margin between $\mathrm{pH}_{\mathrm{v}}$ and $\mathrm{pH}_{\mathrm{n}}$. On the other hand, patients whose urines had $\mathrm{pH}_{\mathrm{v}}$ values consistently lower than their $\mathrm{pH}_{\mathrm{n}}$ values did not block their catheters. If the safety margin between $\mathrm{pH}_{\mathrm{v}}$ and $\mathrm{pH}_{\mathrm{n}}$ can be increased by elevating $\mathrm{pH}_{\mathrm{n}}$, it raises the possibility of an alternative to trying to control the activity of urease-producing bacteria as a strategy for controlling catheter encrustation. Suller et al. (2005), in a study of urine from healthy volunteers, found that it was possible to manipulate $\mathrm{pH}_{\mathrm{n}}$. Simply by increasing fluid and citrate intake, the $\mathrm{pH}_{\mathrm{n}}$ of urine could be elevated to values that are rarely achieved even in $P$. mirabilis-infected urine. The aim of the present study was to examine whether manipulation of $\mathrm{pH}_{\mathrm{n}}$ in these ways modulated the rate at which crystalline biofilm formed on catheters in laboratory models of the catheterized bladder infected with $P$. mirabilis. 


\section{METHODS}

Bacterial strain and culture media. The test organism used in this study, P. mirabilis NSM6, was a clinical isolate from the encrusted catheter of a patient undergoing long-term indwelling catheterization. The artificial urine used in the experimental work was based on that devised by Griffith et al. (1976) and contained calcium chloride $\left(0.49 \mathrm{~g} \mathrm{l}^{-1}\right)$, magnesium chloride hexahydrate $\left(0.65 \mathrm{~g} \mathrm{l}^{-1}\right)$, sodium chloride $\left(4.6 \mathrm{~g} \mathrm{l}^{-1}\right)$, disodium sulphate $\left(2.3 \mathrm{~g} \mathrm{l}^{-1}\right)$, trisodium citrate dihydrate $\left(0.65 \mathrm{~g} \mathrm{l}^{-1}\right)$, disodium oxalate $\left(0.02 \mathrm{~g} \mathrm{l}^{-1}\right)$, potassium dihydrogen phosphate $\left(2 \cdot 8 \mathrm{~g} \mathrm{l}^{-1}\right)$, potassium chloride $\left(1.6 \mathrm{~g} \mathrm{l}^{-1}\right)$, ammonium chloride $\left(1.0 \mathrm{~g} \mathrm{l}^{-1}\right)$, urea $\left(25 \mathrm{~g} \mathrm{l}^{-1}\right)$ and gelatin $\left(5 \cdot 0 \mathrm{~g} \mathrm{l}^{-1}\right)$. The $\mathrm{pH}$ of the medium was adjusted to $6 \cdot 1$ and then sterilized by membrane filtration. Tryptone soya broth (Oxoid) was prepared separately, autoclaved and added to the sterile basal medium to a final concentration of $1.0 \mathrm{~g} \mathrm{l}^{-1}$. The $\mathrm{pH}$ of the urine containing citrate at $3 \cdot 0 \mathrm{~g} \mathrm{l}^{-1}$ was $6 \cdot 3$. All of the urines used in the experiments with citrate were adjusted to this $\mathrm{pH}$ value. Cysteine lactose electrolyte-deficient agar (Oxoid) was used for the enumeration of viable cells in urine.

The bladder model. The bladder model has been described previously (Stickler et al., 1999). In essence, it consisted of a glass chamber maintained at $37^{\circ} \mathrm{C}$ by a water jacket. Each model was sterilized by autoclaving and a size $14 \mathrm{Ch}$ all-silicone catheter (Bard) was inserted into the chamber through an outlet at the base. The catheter retention balloons were inflated with $10 \mathrm{ml}$ sterile water and the catheters were connected to drainage bags in the normal way. Sterile artificial urine was pumped into the chambers so that residual volumes collected below the catheter eyeholes before flowing through the drainage tube to the collecting bags.

Experimental protocol. Sets of models were assembled and supplied with artificial urine up to the level of the catheter eyeholes. The urine supply was then switched off and $10 \mathrm{ml}$ artificial urine was removed from the bladder chamber and replaced with a $4 \mathrm{~h}$ artificial urine culture $(10 \mathrm{ml})$ of $P$. mirabilis NSM6. These cultures were left for $1 \mathrm{~h}$ to establish themselves in the bladder and the urine supply was then resumed at various rates until catheter blockage. The time taken for the catheters to block was recorded. The urinary $\mathrm{pH}$ and the number of viable cells in the urine voided from the model were measured at intervals up to the time of catheter blockage.

Scanning electron microscopy of catheter sections. At the conclusion of each experiment, catheters were removed from the models and sections ( $1 \mathrm{~cm}$ in length) were cut from the region above the retention balloon. In some cases, these sections were examined directly under low-power magnification using the low-vacuum facility of a JEOL 5200 scanning electron microscope. Other sections were perfusion-fixed in $2.5 \%$ glutaraldehyde in $0.1 \mathrm{M}$ Sörensen's buffer $(\mathrm{pH} 8)$ for $4 \mathrm{~h}$ at room temperature or overnight at $4{ }^{\circ} \mathrm{C}$. Subsequently, catheter sections were washed in the buffer for $15 \mathrm{~min}$ before post-fixing using a $1: 1$ solution of $0.05 \mathrm{M}$ buffer $/ 1 \%$ osmium tetroxide for $1 \mathrm{~h}$. A further 15 min wash in distilled water was carried out before samples were dehydrated in an ascending ethanol series. Sublimation dehydration was then performed using hexamethyldisilizane (HMDS), i.e. $70 \%, 90 \%, 100 \%, 100 \%$ ethanol, $100 \%$ ethanol: HMDS $(1: 1)$. Finally, sections were washed twice in $100 \%$ HMDS (15 min each) and left to dry in air. The samples were gold sputter-coated (Edwards S150P sputter-coater) and visualized using a Philips XL-20 scanning electron microscope with an accelerating voltage of $20-25 \mathrm{kV}$.

Determination of $\mathbf{p H}_{\mathbf{n}}$ of urine. Evaluation of $\mathrm{pH}_{\mathrm{n}}$ was based on the method described by Choong et al. (1999). Urine was maintained at $37^{\circ} \mathrm{C}$ and samples were alkalinized in increments of $0 \cdot 2 \mathrm{pH}$ units with $1 \mathrm{M}$ sodium hydroxide solution up to a $\mathrm{pH}$ of 10. At each increment, the $\mathrm{OD}_{600}$ was measured against urine at
pH $5 \cdot 0$ as a blank with a Unicam Helios $\gamma$ spectrophotometer. $\mathrm{pH}_{\mathrm{n}}$ was determined from the resulting plot of $\mathrm{pH}$ versus optical density. $\mathrm{pH}_{\mathrm{n}}$ was defined by an abrupt change in the slope of the graph, showing an increase in turbidity. Plotting $\mathrm{pH}$ versus optical density produces two straight-line segments, which intersect at the $\mathrm{pH}_{\mathrm{n}}$. Regression lines were calculated by least-squares analysis for these two portions of the graph and used to determine the $\mathrm{pH}$ at their intersection.

Statistical analysis. One-way ANOVA carried out at $95 \%$ confidence interval was the statistical test of choice for all experiments. This was carried out using Minitab Release 13 software. Where appropriate, the SE of the mean is indicated.

\section{RESULTS AND DISCUSSION}

\section{Effect of fluid intake on catheter encrustation}

The composition of the basic artificial urine that has been used in our previous studies (Morris et al., 1997) on the formation of crystalline biofilm in the bladder model was devised to simulate the urine produced from elderly longterm catheter users who commonly drink very little. In models supplied with this concentrated urine, encrustation forms rapidly and the catheters block in 19-31 h. Patients are often encouraged to increase their fluid intake by nursing staff, but it is difficult to persuade them to take more fluids. It would strengthen the case for increasing fluid intake if there were evidence in the literature to show that this strategy does in fact extend the lifespan of catheters. The results from four replicated experiments performed in the P. mirabilis-infected bladder models (Table 1) showed that when the rate of supply of the urine was doubled and the concentration of the urine halved, the mean times the catheters took to block increased from $24 \cdot 1 \pm 2 \cdot 9 \mathrm{~h}$ to $49 \cdot 5 \pm 6 \cdot 0 \mathrm{~h}$. When the fluid output was further increased to levels that are produced by normal healthy adults, the lifespan of the catheters increased further. Dilution of the urine increased the $\mathrm{pH}_{\mathrm{n}}$ of the urine from $6 \cdot 7$ to $7 \cdot 5$. The $\mathrm{pH}$ of the urine supplied to the model was $6 \cdot 1$; the presence of $P$. mirabilis in the bladder produced increases in urinary $\mathrm{pH}$ values ranging from $8 \cdot 4$ to $9 \cdot 1$. The population density

Table 1. Effect of diluting urine and increasing its flow rate to bladder models colonized by $P$. mirabilis NSM6 on the times all-silicone catheters took to block

\begin{tabular}{|lcc|}
\hline $\begin{array}{l}\text { Urine input into the } \\
\text { models (ml per 24 h) }\end{array}$ & $\begin{array}{c}\mathbf{p H}_{\mathbf{n}} \text { of } \\
\text { urine }\end{array}$ & $\begin{array}{c}\text { Mean time } \pm \mathrm{SE}(\mathbf{h}) \\
\text { catheters took } \\
\text { to } \text { block }^{*}\end{array}$ \\
\hline 720 (neat urine) & $6 \cdot 7$ & $24 \cdot 1 \pm 2 \cdot 9$ \\
1440 (urine diluted $1: 1)$ & $6 \cdot 9$ & $49 \cdot 5 \pm 6 \cdot 0$ \\
2160 (urine diluted $1: 2$ ) & $7 \cdot 3$ & $82 \cdot 1 \pm 2 \cdot 0$ \\
2880 (urine diluted $1: 3$ ) & $7 \cdot 5$ & $125 \cdot 5 \pm 6 \cdot 4$ \\
\hline
\end{tabular}

${ }^{\star}$ The values indicated are means \pm SE of the means calculated from four replicated experiments. These mean values are all significantly different from each other $(P<0 \cdot 05$; ANOVA). 
of the test organism was maintained at $10^{7}-10^{8}$ c.f.u. $\mathrm{ml}^{-1}$ in all of the models throughout the experimental periods.

In further experiments in which the artificial urine was diluted by half but the flow rate was maintained at $720 \mathrm{ml}$ per $24 \mathrm{~h}$, the catheters blocked at $50 \cdot 5 \pm 4 \cdot 6 \mathrm{~h}$ (mean of four replicates). This value was not significantly different $(P=0 \cdot 9)$ from the value of $49 \cdot 5 \pm 6 \cdot 0 \mathrm{~h}$ recorded when this concentration of urine was supplied at double the flow rate. These data suggest that urine concentration rather than flow rate is the important modulating factor in controlling the formation of the crystalline biofilms.

In a previous study (Morris \& Stickler, 2001) on the effect of increasing fluid intake on catheter encrustation, bladder models were supplied with urine collected over an $8 \mathrm{~h}$ period from healthy volunteers who had taken $2 \times 500 \mathrm{ml}$ mineral water or cranberry juice in addition to their normal fluid intake. The amounts of calcium and magnesium deposited on the catheters in $24 \mathrm{~h}$ were found to be significantly less than when models were supplied with urine from the same individuals over $8 \mathrm{~h}$ periods in which they had not supplemented their normal fluid intakes in these ways. Further experiments showed that when models were supplied with an artificial urine simulating a fluid output of $4320 \mathrm{ml}$ per $24 \mathrm{~h}$, catheters drained freely for a 10 day experimental period. It is unlikely that many patients undergoing longterm catheterization could be persuaded to maintain this level of fluid. The results presented in Table 1, however, suggest that even modest increases in fluid intake to normal adult levels could significantly slow catheter encrustation.

\section{Effect of citrate content on urine crystalline biofilm formation}

Suller et al. (2005) showed that increasing the citrate content of urine resulted in an elevation of $\mathrm{pH}_{\mathrm{n}}$. Using flow rates and urinary concentrations equivalent to $1440 \mathrm{ml}$ per $24 \mathrm{~h}$, urine was therefore prepared containing a range of citrate concentrations and supplied to $P$. mirabilis-infected models at $1 \mathrm{ml} \mathrm{min}{ }^{-1}$. The mean times that the catheters took to block are presented in Table 2. The results showed that, in models supplied with urine containing citrate at $1.5 \mathrm{mg}$ $\mathrm{ml}^{-1}$ or above, catheters drained freely for the 7 day experimental period. The $\mathrm{pH}_{\mathrm{n}}$ of the urine rose to 8.3 at $1.5 \mathrm{mg}$ citrate $\mathrm{ml}^{-1}$ and at $3 \cdot 0 \mathrm{mg} \mathrm{ml}^{-1}$, a $\mathrm{pH}_{\mathrm{n}}$ of $9 \cdot 1$ was recorded. The $\mathrm{pH}$ of the urine voided from the models over the course of the experiments again ranged from mean values of 8.5 to $9 \cdot 0$. The population density of the test organism in all of the urines was maintained at $>10^{8}$ c.f.u. $\mathrm{ml}^{-1}$ throughout the experiments.

Suller et al. (2005) also reported that increasing citrate intake by drinking $500 \mathrm{ml}$ pure orange juice per day achieved concentrations of citrate of up to $1 \cdot 2 \mathrm{mg}(\mathrm{ml} \text { urine })^{-1}$ and elevated $\mathrm{pH}_{\mathrm{n}}$ values from $7 \cdot 3$ to $8 \cdot 2$. The results from Table 2 suggest that, at this concentration, the catheter lifespan would be increased significantly.
Table 2. Effect of increasing the citrate concentration of urine supplied to models colonized by $P$. mirabilis NSM6 on the times catheters took to block

\begin{tabular}{|lcc|}
\hline $\begin{array}{l}\text { Citrate content } \\
\left(\mathbf{m g ~ m l}^{-\mathbf{1}}\right) \text { in } \\
\text { urine }\end{array}$ & $\begin{array}{c}\mathbf{p H}_{\mathbf{n}} \text { of } \\
\text { urine }\end{array}$ & $\begin{array}{c}\text { Mean time } \pm \text { SE }(\mathbf{h}) \\
\text { catheters took } \\
\text { to } \text { block }^{*}\end{array}$ \\
\hline $0 \cdot 0$ & $6 \cdot 7$ & $32 \cdot 3 \pm 3 \cdot 5$ \\
$0 \cdot 41$ & $7 \cdot 4$ & $66 \cdot 3 \pm 6 \cdot 7$ \\
$1 \cdot 0$ & $8 \cdot 2$ & $108 \pm 5 \cdot 5$ \\
$1 \cdot 5$ & $8 \cdot 3$ & $>168$ \\
$2 \cdot 0$ & $8 \cdot 5$ & $>168$ \\
$3 \cdot 0$ & $9 \cdot 1$ & $>168$ \\
\hline
\end{tabular}

${ }^{\star}$ The values indicated are means \pm SE of the means calculated from four replicated experiments. The mean values quoted are all significantly different from each other $(P<0 \cdot 05$; ANOVA).

Scanning electron micrographs of the biofilms that developed on these catheters, taken using the low-vacuum facility of the microscope, illustrated that the higher the citrate concentration of the urine supplied to the model, the less the catheter lumen was occluded by the biofilm (Fig. 1). Micrographs taken at high magnification after fixation and dehydration demonstrated that the biofilm formed at $24 \mathrm{~h}$ in the presence of urine containing $0.41 \mathrm{mg}$ citrate $\mathrm{ml}^{-1}$ contained extensive deposits of poorly crystalline material typical of carbonate apatite (Fig. 2). In contrast, at concentrations of citrate of $1.5 \mathrm{mg} \mathrm{ml}^{-1}$ and above, there was no sign of crystal formations in the biofilms at this time (Fig. 3). At 7 days, the micrographs revealed some signs of apatite in the basal layers of the biofilm formed in the presence of urine containing citrate at $1.5 \mathrm{mg} \mathrm{ml}^{-1}$ (Fig. 4). At higher concentrations of citrate, however, the biofilms were devoid of crystalline material (Fig. 5). It was interesting that layers of elongated swarmer cells were visible in the biofilms that developed in urine containing elevated citrate levels. It is possible that, in the absence of extensive crystallization, the swarmers have a role in biofilm formation on catheters.

Burr \& Nuseibeh (1997) examined the relationship between catheter blockage and urine composition in patients with spinal injuries undergoing long-term indwelling bladder catheterization. They reported that a group who had been designated non-blockers on the basis that their catheters lasted for at least 6 weeks without blocking had relatively high mean urinary outputs of 3.081 per $24 \mathrm{~h}$. While there was no indication of the numbers of these patients that were infected with $P$. mirabilis and thus at risk of catheter encrustation, they came to the conclusion that, for patients prone to catheter blockage, a high and uniform rate of fluid intake should be mandatory. The results presented in Table 1 provide support for this strong recommendation.

Wang et al. (1994) examined the effect of citrate on the crystallization of salts from urine induced by the enzyme 

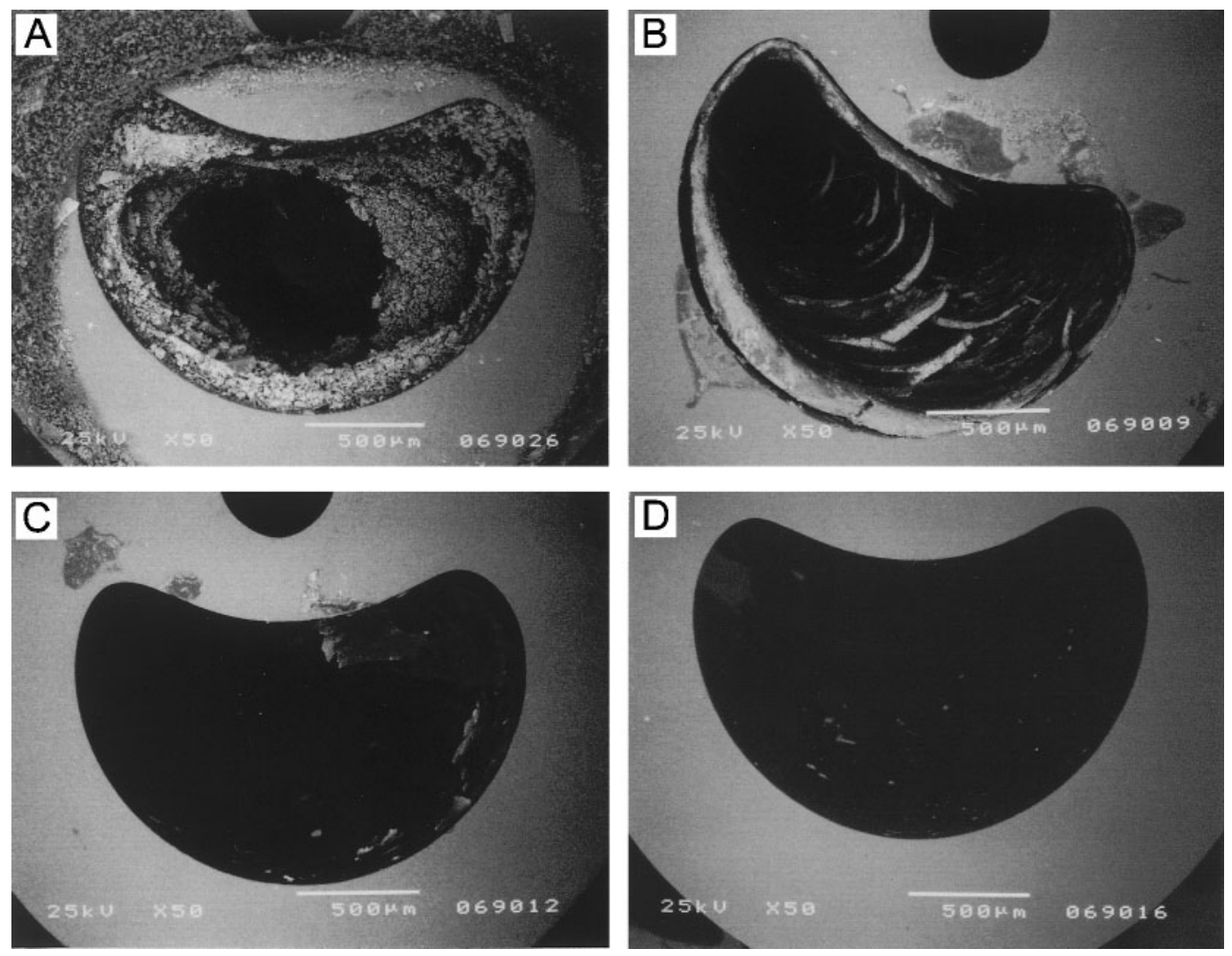

Fig. 1. Scanning electron micrographs of sections of catheters taken from just below the eyeholes of catheters after removal from models that had been supplied with urine containing various citrate concentrations. (A) The section shown was removed after it had blocked at $64 \mathrm{~h}$ in a model that had been supplied with urine containing citrate at $0.41 \mathrm{mg} \mathrm{ml}^{-1}$. (B-D) The section shown was removed after 7 days from a model supplied with urine containing citrate at 1.5 (B), 2.0 (C) or 3.0 (D) $\mathrm{mg} \mathrm{ml}^{-1}$.

urease. They found that crystal growth and the resulting precipitation of calcium and magnesium salts in urine were inhibited when citrate was added up to a concentration of $4 \mathrm{mM}\left(0 \cdot 76 \mathrm{mg} \mathrm{ml}^{-1}\right)$. These effects were also achieved by increased oral intake of citrate. Furthermore, they suggested that a study of the effect of oral citrate as a prophylactic remedy against encrustations on indwelling catheters might be rewarding. The results presented in Table 2 and Figs 1-5

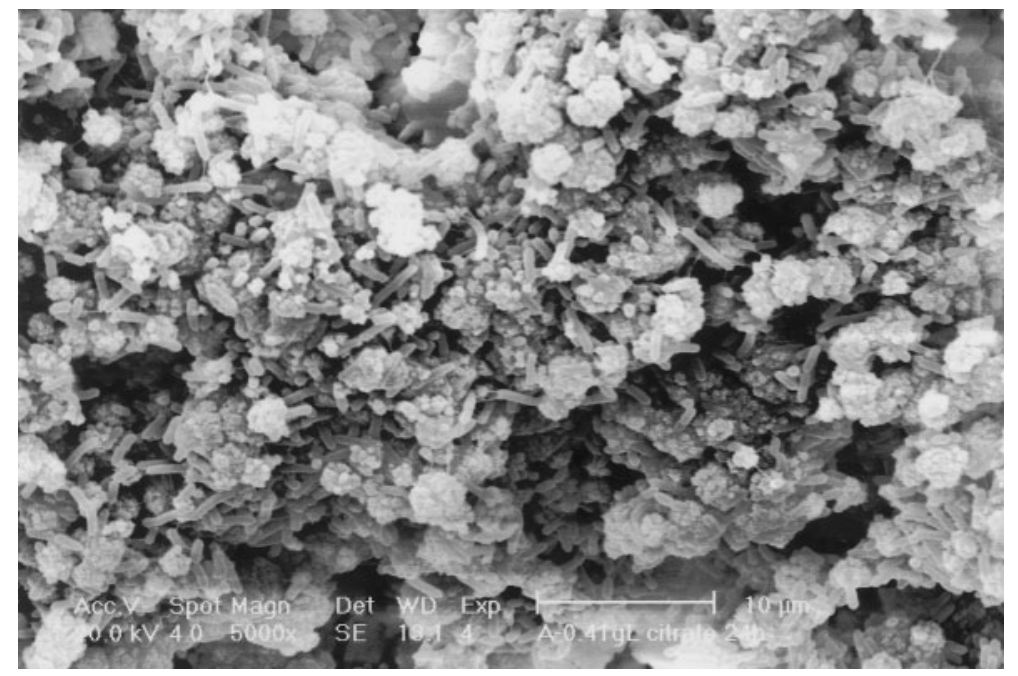

Fig. 2. Scanning electron micrograph of a section of $P$. mirabilis biofilm formed on a catheter that was removed after $24 \mathrm{~h}$ incubation in a model supplied with urine containing $0.41 \mathrm{mg}$ citrate $\mathrm{ml}^{-1}$. Extensive amorphous crystalline material typical of apatite can be seen throughout the bacterial biofilm. 


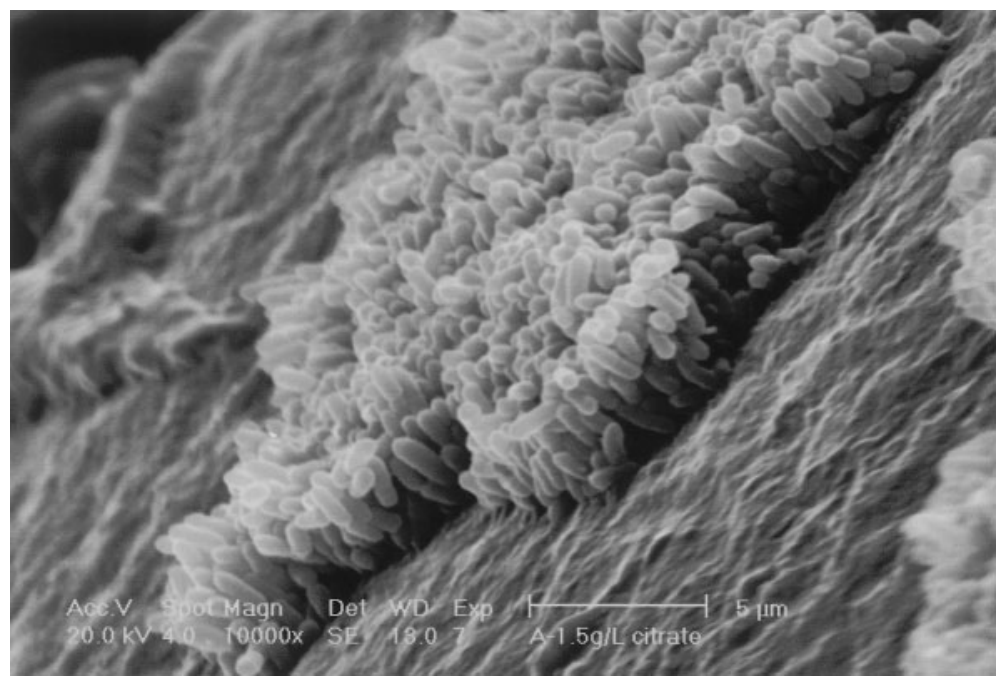

Fig. 3. Micrograph of the surface of a catheter removed after $24 \mathrm{~h}$ from a model supplied with urine containing citrate at $1.5 \mathrm{mg} \mathrm{ml}^{-1}$. The biofilm is sparse and is composed of micro-colonies of cells with no signs of crystalline material.

demonstrate that increasing the concentration of citrate in urine (to levels that are achievable by drinking juice from oranges or other citrus fruits) reduces the deposition of crystalline material in the catheter biofilm. Viable cell counts of $>10^{8}$ c.f.u. $\mathrm{ml}^{-1}$ and $\mathrm{pH}$ values of $>8 \cdot 5$ were achieved in the control and in all of the citrate-containing urines. It is unlikely, therefore, that the results observed on the reduction of catheter encrustation were due to direct effects of citrate on the growth or metabolism of P. mirabilis.
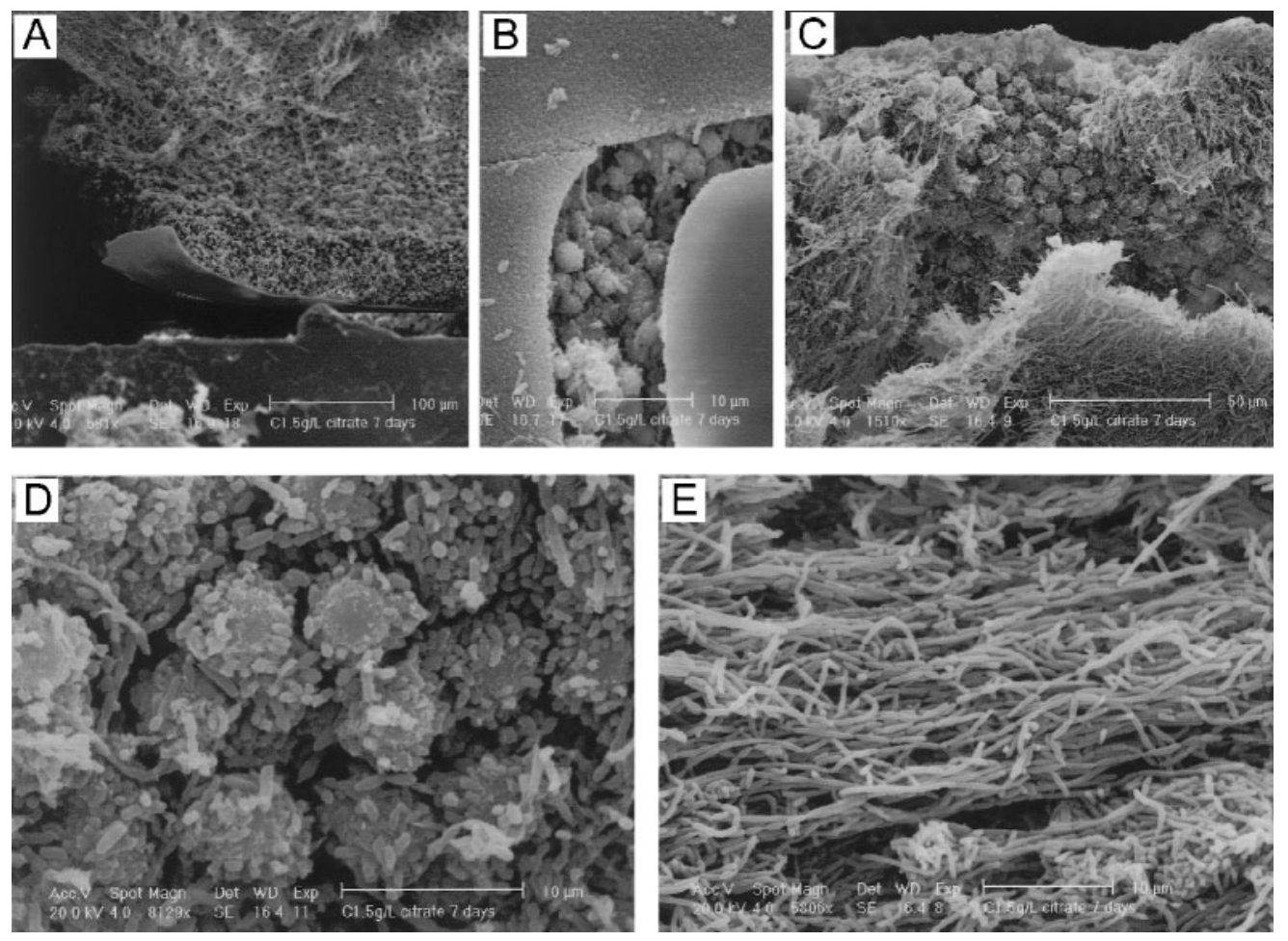

Fig. 4. A series of micrographs illustrating the structure of a biofilm on a catheter removed after 7 days from a bladder model

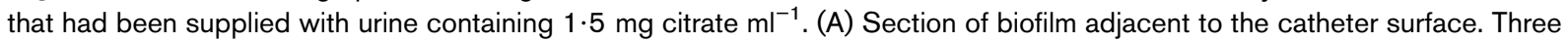
distinct structural layers are apparent: a compact basal layer, on which a regular array of poorly crystalline structures has formed and above which is a mass of elongated bacterial cells. (B) View of the foundation layer, which has fractured revealing the apatite-like structures. (C) Surface view of the biofilm showing the three regions described in (A). (D) The crystalline structures at higher magnification. (E) A mass of elongated swarmer cells on the biofilm surface. 

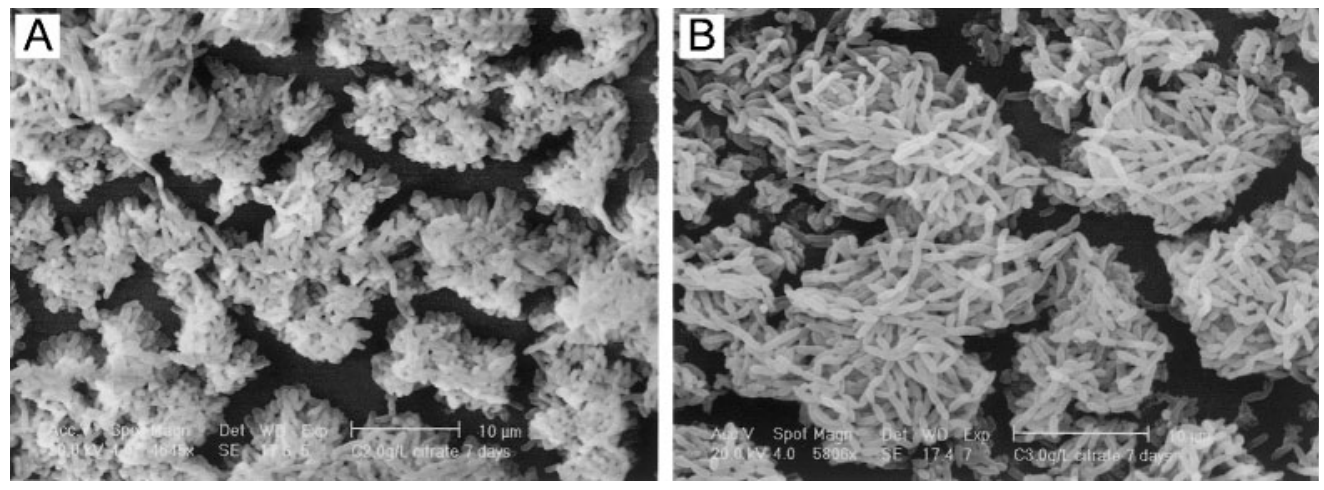

Fig. 5. Micrographs of the surfaces of catheters removed after 7 days from models supplied with urine containing 2 (A) and 3 (B) $\mathrm{mg}$ citrate $\mathrm{ml}^{-1}$. The biofilms are poorly developed surface communities and there is no sign of crystal formation.

In conclusion, it is clear that diluting urine and increasing its citrate concentration results in elevation of $\mathrm{pH}_{\mathrm{n}}$ and a consequent reduction in the rate of deposition of crystalline $P$. mirabilis biofilm on urinary catheters. These observations should encourage a clinical trial to examine the effect of increasing a patient's fluid intake with citrate-containing drinks on the encrustation and blockage of catheters.

\section{REFERENCES}

Burr, R. G. \& Nuseibeh, I. M. (1997). Urinary catheter blockage depends on urine $\mathrm{pH}$, calcium and rate of flow. Spinal Cord 35, 521-525.

Choong, S. K. S., Hallson, P., Whitfield, H. N. \& Fry, C. H. (1999). The physicochemical basis of urinary catheter encrustation. Br J Urol Int 83, 770-775.

Choong, S. K. S., Wood, S., Fry, C. H. \& Whitfield, H. N. (2001). Catheter associated urinary tract infection and encrustation. Int $J$ Antimicrob Agents 17, 305-310.

Griffith, D. P., Musher, D. M. \& Itin, C. (1976). Urease. The primary cause of infection-induced urinary stones. Invest Urol 13, 346-350.

Hedelin, H., Bratt, C. G., Eckerdal, G. \& Lincoln, K. (1991). Relationship between urease-producing bacteria, urinary $\mathrm{pH}$ and encrustation on indwelling urinary catheters. Br J Urol 67, 527-531.
Kunin, C. M. (1997). Care of the urinary catheter. In Urinary Tract Infections: Detection, Prevention and Management, 5th edn, pp. 226-278. Baltimore: Williams \& Wilkins.

Mathur, S., Suller, M. T. E., Stickler, D. J. \& Feneley, R. C. L. (2006). Prospective study of individuals with long-term urinary catheters colonized with Proteus species. Br J Urol Int 97, 121-128.

Morris, N. S. \& Stickler, D. J. (2001). Does drinking cranberry juice produce urine inhibitory to the development of crystalline, catheterblocking Proteus mirabilis biofilms? Br J Urol Int 88, 192-197.

Morris, N. S., Winters, C. \& Stickler, D. J. (1997). Which indwelling urethral catheters resist encrustation by Proteus mirabilis biofilms? $\mathrm{Br}$ J Urol 80, 58-63.

Morris, N. S., Stickler, D. J. \& McLean, R. J. C. (1999). The development of bacterial biofilms on indwelling catheters. World J Urol 17, 345-350.

Stickler, D. J. \& Zimakoff, J. (1994). Complications of urinary tract infections associated with devices for long-term bladder management. J Hosp Infect 28, 177-194.

Stickler, D. J., Morris, N. S. \& Winters, C. (1999). Simple physical model to study formation and physiology of biofilms on urethral catheters. Methods Enzymol 310, 494-501.

Suller, M. T. E., Anthony, V. J., Mathur, S., Feneley, R. C. L. \& Stickler, D. J. (2005). Factors modulating the $\mathrm{pH}$ at which calcium and magnesium phosphates precipitate from human urine. Urol Res 33, 254-260.

Wang, Y. H., Grenabo, L., Hedelin, H. \& Pettersson, S. (1994). The effects of sodium citrate and oral potassium citrate on ureaseinduced crystallization. Br J Urol 74, 409-415. 